None were observed May 31. Oviposition continued to June 8, p. m., at the latest, and the total number counted was 99-51 up to June 2, a.m., 41 between 2, a.m. and 4, p. m., 7 between 4, p. m. and $8, \mathrm{p} . \mathrm{m}$. They were laid on the less compact or looser surface of the felt, and some were placed quite deeply among the loose fibers. Evidently they are not always placed singly, for in one instance a group of four was found, and several occurred in pairs. The moth died the evening of June 9. The eggs (infertile in this case) were white to the unaided eye and under an ordinary hand lens, but practically colorless when magnified more highly; oval to ovoid in shape, but a few were somewhat reniform, resembling a type of bean; surface somewhat roughened, marked with nearly spherical, squarish, or elongate shallow depressions, with very narrow intervening ridges. Whether the roughened surface, and the subreniform shape, was due to the age of the eggs-for on June 9, when they were examined, a large proportion had already collapsed-the writer cannot say, although, he might state, it did not appear so. Eighteen were measured and were found to be .49 to $.66 \mathrm{~mm}$. long and .27 to $.34 \mathrm{~mm}$. wide. The longest were generally the broadest.

The present record, it might be added, adds to the accumulating evidence, seemingly, that this species rather than Tinea pellionella Linn. (the case-making moth) is the more common species in the North.

How is the marked difference in degree of activity and sensitivity manifested by the larvæ to be explained? Is it a matter of individuality? Or, in view of the resulting difference in sex, is it a matter of sex?

\title{
ECOLOGICAL RELATIONS OF THE LEPIDOPTEROUS GENUS DEPRESSARIA (GECOPHORIDA).
}

\author{
By Miss Jay R. Traver, \\ Department of Entomology, Cornell University.
}

The members of a group of animals or plants, closely allied to one another in a systematic sense, may yet differ rather widely in their habits of life. While fitted for the same general type of environment, they nevertheless show considerable variation in their adap- 
tations to certain phases of that environment. Especially is this true of the ways in which they obtain the two prime necessities of life-food and shelter. The genus Depressaria, of the Lepidopterous family Ecophoridæ, illustrates such variation of habits. As regards this rather large genus, many facts of a biologic nature remain still to be worked out. However, from the data available, some interesting ecological relations have been noted.

In treating this genus, the catalogues of Staudinger and Rebel for European forms, and of Dyar for North American forms, have been followed, with additions of such as have been described since these publications, and of such exotic forms as are given in a few other sources. From the British Museum Catalogue, seven species are listed for which no references could be found. These are $D$. acerbella, Africa, a doubtful member of the genus; lewinella, melesella, sobriella, convictella and absumptella, Australia; and moderatella, Tasmania. If these species have been transferred from Depressaria, no account of such transfer could be found. From Cotes and Swinhoe's Moths of India, seven species are listed, omitting D. gossypiella, which is no longer placed in this genus. One species is also listed from the Biologia Centrali-Americana.

The genus as here treated consists of two hundred and fortynine species, distributed throughout most parts of the world, yet occurring mainly in Central Europe. The table of distribution is as follows:

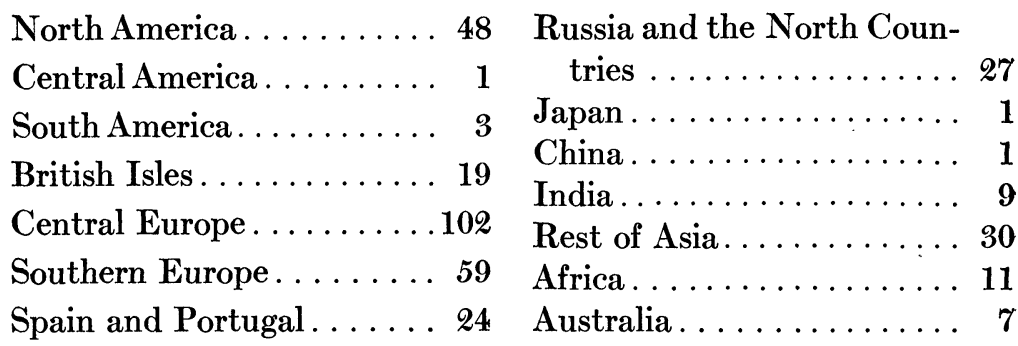

If the grouping be given for continents, Europe has by far the greatest number, and these are in the main located in central Europe. Stainton says: "Though most of the European species seem to be widely distributed, a few are restricted to the south, and some are peculiar to the north." It is evident that this statement still holds good, though the number of recognized species is now nearly three times that known by Stainton. 
Of these two hundred and forty-nine species, the life-histories of ninety-four are recorded. H. T. Stainton has probably given us the most material, in a compact form but very comprehensive, in his Natural History of the Tinenia. In volume six of this work, he treats of the life-histories of twenty-four species, while in volume twelve he adds twelve more to the list. Chretien, likewise, among recent entomologists, seems to have devoted much time to lifehistory work among the smaller forms, and he has given us much valuable data of this sort for the genus Depressaria. Besides the thirty-six species treated by Stainton, fifty-eight others have been reared or otherwise studied by other workers, so that their habits are known. For one hundred and eighteen of the remaining species merely distribution and description, usually of adult alone, but occasionally of larva and pupa also, have been given. Complete references for thirty-three of these species were not available. The references to the rest of the species include likewise some mention of the food plant of the larva. That is to say, for 53 per cent. of the genus, something of the life-history and habits is known. Since an ecological study of a group depends mainly on such material as this, it is clearly impossible to give more than an estimate of that group, when so much remains to be determined. The tables given are, therefore, in no sense complete, but merely an arrangement of such biologic knowledge of the group as has been verified.

Ten of the species are known to be gregarious in their larval habits, a number of larvæ living together on the same leaf or in the same umbel. Twenty-two, however, are recorded as being solitary in the larval state, while no mention is made of the social habits of any of the others.

Of the seasonal distribution, no very definite facts could be learned. Several are known to pass the winter as imagos, a few as larvæ, and others in the egg stage. Mention is made by Chretien of one species, $D$. halophilella, which "lives during the winter in the interior of the stems, the shoots and the pulpy leaves of Crithmum maritimus." It seems to be generally accepted that the genus is single-brooded and that the eggs do not hatch till rather late in the spring. In the case of those passing the winter in the imago form, it is several times noted that the adult insect is rarely seen in the fall, but more commonly in the spring after its hibernation.

Stainton writes of the adult insects: "The perfect insects of the 
genus Depressaria live very retired, and species may be excessively abundant, yet never seen in the perfect state. Many of the species hibernate in the perfect state, and some, which are seldom seen before hibernation, are comparatively common in the spring; but others do not show themselves either before or after hibernation." He further mentions that the adults may often be taken after dusk, on the food plants, when they are found crawling up the stems. "When dislodged from any place of retreat, they shuffle along with considerable rapidity till they have attained a fresh place of concealment." The adults are likewise mentioned by Stainton as being fond of sweets.

In the main the pupal state seems to be passed on or near the surface of the ground, usually under stones, dried leaves or other rubbish. Thirty-nine are reported as pupating thus, usually within a light silk cocoon. But there are others that remain in the top of the plant for pupation, either in the umbels or in the silken webs in which they found shelter as larvæ; seventeen are recorded in this category. One of these remains within a silken gallery which it spun inside a leaf, the outer edges of which were drawn up and securely fastened. Still a third type of pupal habit is known, that of pupating within the stem of the plant. Three species belong here. One of these has been described as burrowing into the stem for a short distance, then up, after which it erects, across the hollowed stem and above the entrace hole, a silken platform, upon which the pupal state is passed.

The habits of the larva are perhaps of greater interest, as these are determined mainly by the need for food and shelter. Their methods of providing themselves with shelter may be considered first. Twenty-four are leaf-rollers, usually rolling part of the leaf and securing it with bands of silk, thus forming a shelter for themselves when they are at rest. Twenty-three are makers of tubes, either wholly of silk, or more often partly of leaves or flower heads and partly of silk. Within this tube they find safety. Still others, fifty-seven of which are recorded, may be called web spinners, since they form irregular webs, and with these silken strands draw leaves of a shoot or flower-heads in an umbel more or less together; or perhaps merely parts of a leaf are thus held and fastened. Some larvæ are both web spinners and tube makers or leaf rollers. Three are known to be leaf miners, at least in the 
earlier stages of their larval life. Five others are stem borers during their lives as larvæ.

The majority of the larvæ feed upon the leaves of their respective food plants. Packard writes: "The larvæ are extremely active and feed on a variety of substances; some in rolled-up leaves of composite plants, some in the leaves and others in the umbels of umbelliferous plants." Sixty-seven are recorded as leaf-feeders. One feeds partly upon bark and twigs. Of the six which bore into stems, in only one case was mention made of the part of the plant fed upon; in this, the larva fed on the stem. Hence it is doubtful whether the other five may be considered to be stem feeders, or whether they merely obtain shelter from the hollowed stem, coming forth to feed upon other parts of the plant. Eighteen feed upon the buds or flowers, while four others feed upon the fruit also, after the flowers are gone. This distribution leaves practically no part of the plant, except the root, which members of this genus do not use for food.

Stainton writes: "The food of the larvæ is very various, some of them feeding on the leaves of composite plants, others, and by far the greater portion, in the umbels or on the seeds or leaves of different species of Umbelliferæ; again the larvæ of two species feed on the sallow, whilst the Hypericum perforatum affords a pabulum to another species." Sixteen different plant families are represented among the food plants of the larvæ of this genus. Of these, Umbelliferæ easily takes the lead, furnishing fifty-nine species of larvæ with food. Compositæ stands second only in favor among this group, with thirty-three larvæ feeding upon it. Leguminoseæ are fed upon by eleven species, Cupuliferæ by four and perhaps five. In one instance note was made of the fact that the imago was taken from an oak, which probably means that the larvæ of that species feed upon the oak. Five are known to feed upon Rutaceæ, two upon Euphorbiaceæ, two upon Hypericaceæ, two upon each of the families of Salicaciæ and Coniferæ, while the families Cistaceæ, Lythraceæ, Rosaceæ, Burseraceæ, Malvaceæ, Rhamnaceæ and Polygonaceæ are likewise represented, one species of larva being recorded from each of these families.

Only three of the genus are known to be of economic importance, $D$. heracliana is known as the parsnip web-worm, and an account of its depredations, with methods of control, may be found in 
Sanderson's Insect Pests (p. 417). D. groteella, feeding upon hazel and $D$. robiniella upon locust, are both at times injurious to forest trees. Accounts of these may be found in Packard's Insects Injurious to Forest Trees, with methods of control should the larvæ become a pest.

The following is a summary of what is now known of the habits of the genus:

Social habits.

Pupation.

Gregarious........... 10 On ground .......... 39

Solitary............ 22 In umbels or leaves...... 17

Hibernation. In stem............ 3

As egg............ 3 In gallery.......... 1

As larva............ 4 Food plants.

As adult. . . . . . . . . 19 Umbelliferæ.......... 59

Feeding habits. $\quad$ Compositæ........... 33

On leaves...........6 67 Leguminosæ.......... 11

On buds or flowers....... 18 Cupuliferæ........... 5

On bark or twigs....... 1 Rutaceæ........... 5

On stem............ 6 E Euphorbiaceæ......... 2

On fruit............ 4 Hypericaceæ......... 2

Economic importance. Salicaceæ............ 2

D. groteella ......... on hazel Coniferæ............ 2

D. robiniella ....... on locust Cistaceæ........... 1

D. heracliana...... on parsnip Lythraceæ.......... 1

Methods of obtaining shelter.

Leaf rollers. . . . . . . . . . 24

Tube makers. . . . . . . . 23

Web spinners......... 57

Leaf miners.......... 3

Stem borers........... 5

Rosaceæ............. 1

Burseraceæ........... 1

Malvaceæ............ 1

Rhamnaceæ........... 1

Polygonaceæ........... 1

\section{BiBLIOGRAPHY.}

(Supplementary to catalogues cited.)

Barnes, Wm., and J. McDunnough. Check list of the Lepidoptera of Boreal America, Decatur. (1917.)

Busck, August. Descriptions of North American Tinenia. Proc. Ent. Soc. Washington, Vol. 9, pp. 88-92. (1908.) 
Chretien, Pierre. Déscriptions de deux espèces nouvelles de Depressaria d'Algérie (Lep.) Ann. Soc. Ent. France, pp. 276-277. (1907.)

—. Les chenilles des Buplèvres. Le Naturaliste, Vol. 29, p. 89. (1907.)

- - Microlepidoptères nouveaux pour la faune française. Ibid., Vol. 30, pp. 66, 126-127. (1908.)

- - Microlepidoptères nouveaux de France et de Corse. Ibid., t. c., pp. 186-187. (1908.)

- - Déscription complémentaire de Depressaria ferocella Chret. Bull. Soc. Ent. France, p. 182. (1914.)

——— Déscription d'une espèce nouvelle de Depressaria. Ibid., t. c., p. $159 . \quad$ (1914.)

——. Lepidoptères du Nord de l'Afrique. Ibid., pp. 341-344. (1915-16.)

Cotes, E. C., and C. Swinhoe. A Catalogue of the Moths of India. Indian Museum, Calcutta. (1887.)

Dyar, Harrison G., and C. H. Fernald. A list of North American Lepidoptera and Key to the Literature of this Order of Insects. Bull. U. S. Nat. Mus., No. 52. (1902.)

Engel, Henry. New Microlepidoptera. Ent. News, Vol. 18, p. 276. (1907.)

Fuchs, A. Alte und neue Kleinfalter der europäischen Fauna. Stettiner Ent. Zeitg., Vol. 64, p. 244. (1903.)

Krone, W. Neubeschreibungen einiger Arten und Varietäten von

Microlepidopteren. Jahresb. Wiener Ent. Ver., Vol. 21, pp. 39-42. (1910-11.)

Krulikovsky, L. Petites notices Lepidoptérologiques IX. Rev. Russe d'Ent. p. 181. (1907.) (In Russian.)

Meyrick, E. Descriptions of Indian Microlepidoptera. Journ. Bombay Nat. Hist. Soc., Vol. 20, p. 166. (1910.)

—— Descriptions of South African Microlepidoptera III. Ann. Transvaal Mus., pp. 74, 316. (1911.)

- - Exotic Microlepidoptera I, pp. 115, 253. Marlborough Witts. (1914.)

- Descriptions of South African Microlepidoptera. Ann. South African Mus., Vol. 10, p. 249. (1914.)

tera. Trans. Ent. Soc. Sweden, Vol. 15, pp. 210-211. (1915.) 
- Lepidoptera aus Morea. Machtrag 2. Berliner Ent. Zeits., Vol. 50, Nachtr. 2, p. $311 . \quad$ (1906.)

- Z Z Zei neue Saturniidæ aus Deutsch-Ostafrika. Ann. k. k. Naturhist. Hofmus. Wien, Vol. 19, p. 360. (1904.)

Strand, E. Depressaria arctica Strand, n. sp. Arch. Math. Naturvidenskab., Vol. 24, (1903.)

Staudinger, Otto, and Hane, Rebel. Catalog der Lepidopteren des Palæarctischen Faunengebietes. Berlin. (1901.)

Walsingham, Thomas. Spanish and Moorish Microlepidoptera. Ent. Monthly Mag., Vol. 39, 2d ser., Vol. 14, pp. 266-268. (1903.)

Vol. 43, 2d ser., Vol. 18, pp. 214-215. (1907.)

- - Microlepidoptera of Teneriffe. Proc. London Zoöl. Soc., 1907, p. 958. (1908.) (1909-15.)

NOTES ON THE EARLY STAGES AND LARVAL LOCOMOTION OF LEIA BIVITTATA SAY ${ }^{1}$ (DIPTERA).

By Harry B. Weiss, New Brunswick, New Jersey.

Several specimens of this fungus gnat were bred during the last of March from the partly decomposed fruiting bodies of Lenzites betulina, which had been collected during February on an old stump at New Brunswick, N. J., and kept in a warm room. It is evidently a well distributed species as it was described by Say from Indiana, and Johannsen ${ }^{2}$ records it from Connecticut, Rhode Island, North Carolina, Wisconsin, Illinois, Kansas, Minnesota, Iowa, Michigan and New York. In Aldrich's Catalogue of North American Diptera it is listed as Neoglaphyroptera bivittata Say, and $\mathrm{Smith}^{3}$ records it under the same name from several points in New Jersey.

Full grown larvæ under observation averaged about $13 \mathrm{~mm}$. in

1 Kindly identified by C. W. Johnson.

2 Fungus Gnats of North America, Part III, p. 290, Maine Agric. Exp. Sta. Bull. 196.

I Insects of New Jersey, N. J. State Mus. Rept. 1909. 

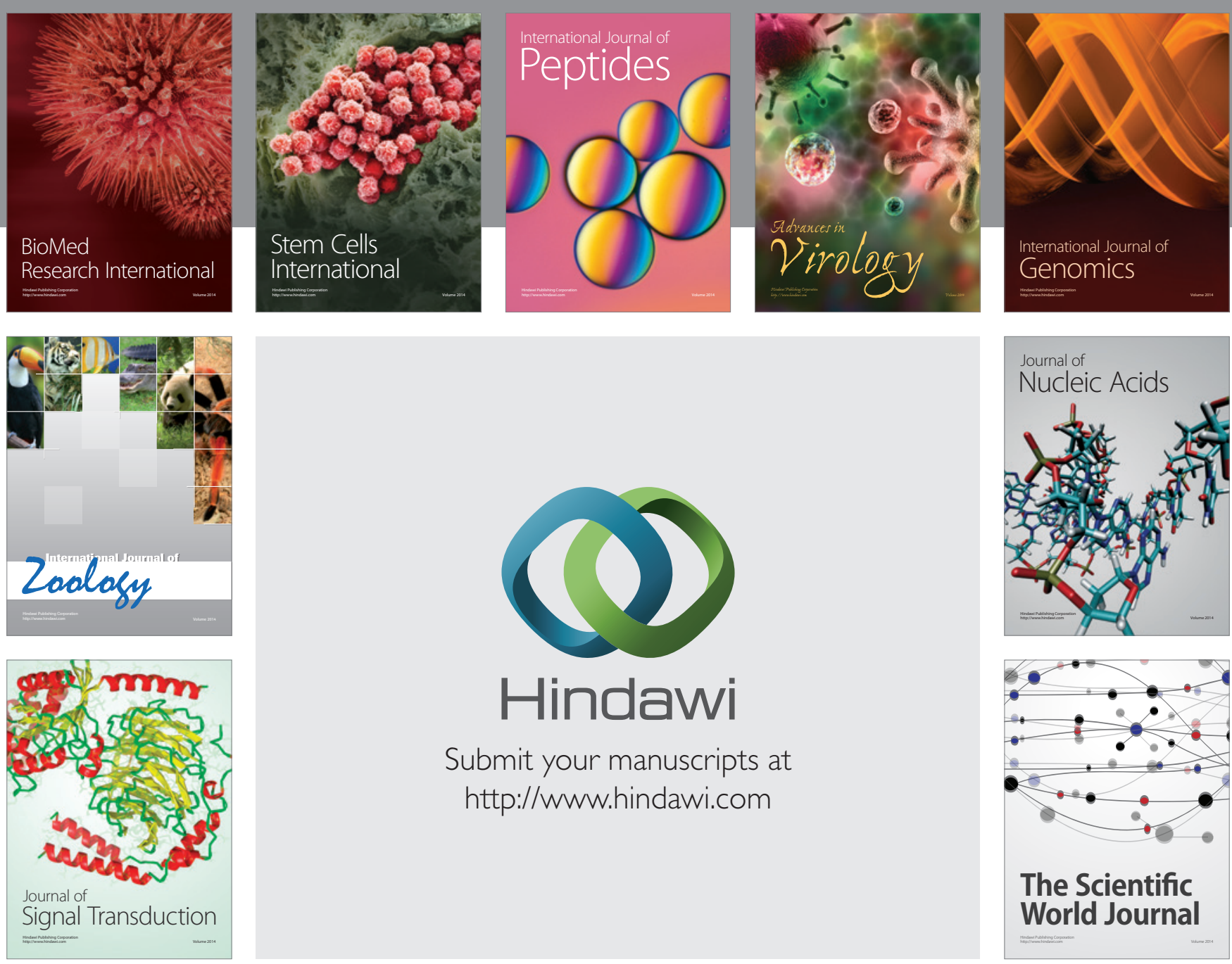

Submit your manuscripts at

http://www.hindawi.com
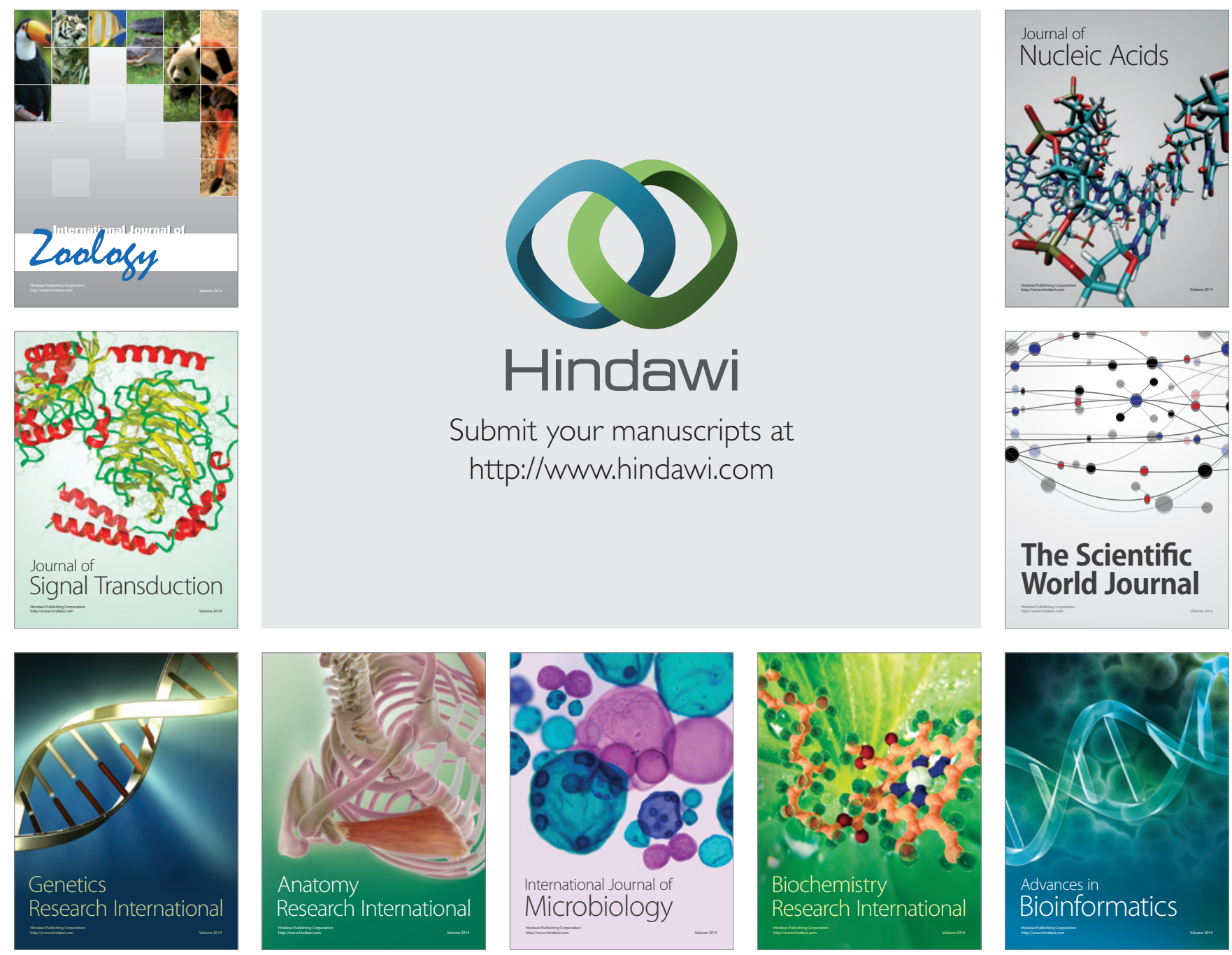

The Scientific World Journal
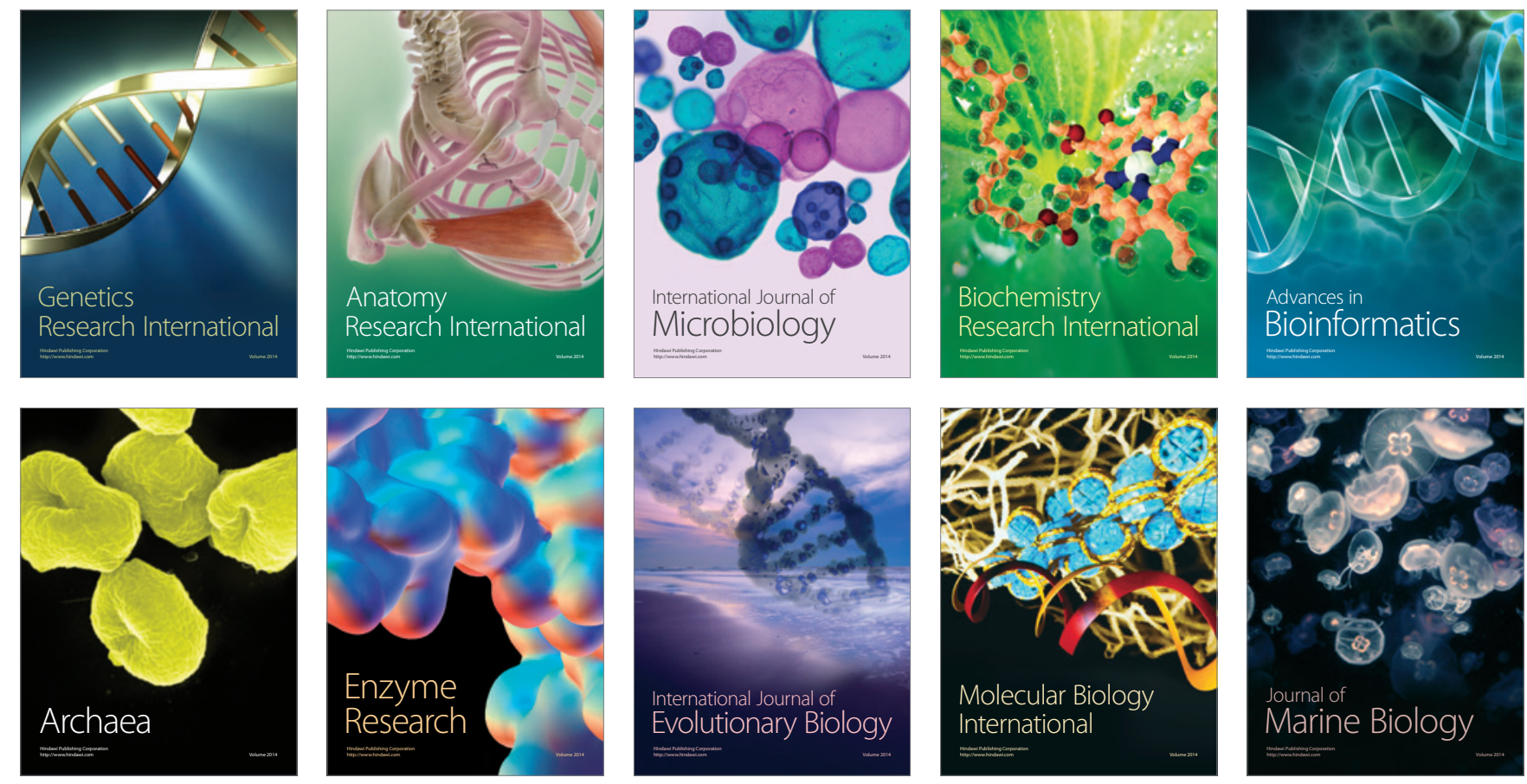